\title{
PHILOLOGY
}

\section{КОНФЛИКТ «ЛИЧНОСТЬ И РЕАЛЬНОСТЬ» В POМАНЕ Ж.-Ф. ТУССЕНА «МЕСЬЕ»}

\author{
Матенова Юлия Умидовна \\ Кандидат филологических наук, дочент \\ Ташкентский государственный педагогический университет, Ташкент, Узбекистан
}

DOI: https://doi.org/10.31435/rsglobal_ws/30122019/6835

\section{ARTICLE INFO}

Received: 19 October 2019

Accepted: 21 December 2019

Published: 30 December 2019

\section{KEYWORDS}

author, philosophical novel genre, comic effect, characters, speech assessment, artistic and visual means. \begin{abstract}
The article is dedicated to the work of Toussin, author of the novel "Monsieur". The novel, written in the style of "minimalism", lacks a logical, consistent narrative. At the same time, scrupulous detailing of all his actions, actions, and conditions prevails. The episodes described in detail are not further developed. Direct allusions of educational literature in the work of Toussin are absent. Toussin's novel "Monsieur", most likely, is a peculiar variation of the game with the philosophical story of the XVIII century, where there is a hidden dialogue between the author and Voltaire.
\end{abstract}

Citation: Matenova Julia Umidovna. (2019) Conflict "Personality and Reality" in the Novel J.-F. Tussen "Monsieur". World Science. 12(52), Vol.2. doi: 10.31435/rsglobal_ws/30122019/6835

Copyright: (C) 2019 Matenova Julia Umidovna. This is an open-access article distributed under the terms of the Creative Commons Attribution License (CC BY). The use, distribution or reproduction in other forums is permitted, provided the original author(s) or licensor are credited and that the original publication in this journal is cited, in accordance with accepted academic practice. No use, distribution or reproduction is permitted which does not comply with these terms.

Жана-Филиппа Туссена (1957 г.р.) причисляют к ряду так называемых «минималистов» (Ж.Эшноз, Э.Шевипар, М.Редоне и другие).*

Ж.-Ф.Туссен - многосторонне и блестяще образованный автор целого ряда книг, переведённых на более чем 30 языков, кинорежиссёр, чутко воспринимающий живопись, искренне интересующийся проблемами науки. Широко известны европейским читателям романы Ж.-Ф.Туссена «Ванная комната» (1985), «Месье» (1986), «Фотоаппарат» (1988), «Умолчание» (1991), «Телевидение» (1997), «Заниматься любовью» (2002). Первые три романа экранизированы, причём, два из них самим писателем. На русский язык переведены его романы «Ванная комната» и «Месье». (Переводчик - И.Радченко).

Художественно-изобразительные средства у Туссена крайне лаконичны и сведены к минимуму, объём его произведений, как правило, не превышает 100 страниц. Свою творческую задачу писатель Ж.Ф. Туссен сформулировал следующим образом: «Я понимаю функцию писателя как нечто живое и забавное... Как писатель я должен переворачивать всё вверх дном, чтобы мое творчество не вылилось в некую раз и навсегда застывшую форму». ${ }^{1}$ Он воспринимал литературное произведение как своеобразную игру с читателем. Д.ф.н. Шервашидзе С.В. полагает, что «романы Туссена - ироничное воспроизведение стихии банальности, в которой ничего не происходит». ${ }^{2}$

\footnotetext{
* Термин «минималисты» появился еще в конце 60-х годов в Америке применительно к деятелям изобразительного искусства, когда творцы-художники достигали необходимого заданного эффекта с помощью самых простых, лаконичных средств. В литературе Франции «минимализм» оформился на рубеже XX и XXI веков

${ }^{1}$ Цитируется по учебнику Шервашидзе С.В. Западно-европейская литература XX века. М.; Флинта, 2010. с.246.

${ }^{2}$ Шервашидзе С.В. - Там же, с. 247.
} 
Рассмотрим в качестве конкретного подтверждения этой характеристики творчества Туссена один из ранних его романов «Месье». Написанный в стиле «минимализма», роман состоит из 66 страниц. В нём отсутствует логичное, последовательное повествование, а состоит это произведение из ряда небольших фрагментов, часто не связанных друг с другом, где приводится подробнейшее описание обычной повседневной жизни персонажа, где не происходит сколько-нибудь значительных событий. При этом преобладает скрупулёзная детализация всех его действий, поступков, обстановки. Эпизоды, подробнейшим образом описанные, не получают дальнейшего развития. Название романа, как и обозначение главного персонажа - «Месье» - вежливое обращение к мужчинам без всякой эмоциональной окраски подразумевает отсутствие каких-либо пристрастий и вкусов, подчеркивает безмерную усредненность обыденного типа. Нельзя не согласиться с мнением проф. С.В. Шервашидзе о том, что «безымянность героя, отсутствие своеобразия являются не только олицетворением неуловимой сущности человеческой природы, но и «метафорой» современного сознания. ${ }^{1}$

Повествование ведётся от 3-го лица. Месье показан и в бытовой обстановке, и на службе. Его служебные обязанности представлены как бесконечное, но обязательное повторение одних и тех же действий, приведение в порядок собственного кабинета на 16 этаже и всех его атрибутов, просмотр ежедневной почты, специализированных журналов, приём посетителей и присутствие на совещаниях у директора, где он неизменно сидел на одном и том же стуле, за спиной мадам ДюбуаЛакур, курировавшей его дела, стараясь оставаться незамеченным.

В сложных нестандартных ситуациях, когда он не знал, что сказать или сделать, Месье успокаивался от повторяющихся бессмысленных действий: сортировки карточек, перебирания бумаг - т.е. имитации деятельности, или постукивания и рассматривания своих пальцев. Тем не менее «Месье легко вписывался в коллектив. При всей своей замкнутости он не чурался разговоров в коридоре, и, потупив глаза, слушал, как коллеги обсуждают тот или иной животрепещущий вопрос. Потом извинялся, что вынужден их покинуть и беспечной походкой удалялся к себе...». ${ }^{2}$ Удивительно и парадоксально, что столь несодержательная служебная деятельность Месье у многих вызывает самое лестное мнение о нем. «Дюбуа-Лакур никогда не подвергала сомнению, и он был ей за это признателен, серьезное отношение Месье к работе. Такое впечатление, будто вы всегда сидите сложа руки, дружески замечала она при случае и проницательно добавляла, что это как раз и есть свойство истинных тружеников». ${ }^{3}$

Комический эффект вызывает эта утрата смысла между пустотой, бессодержательностью поступков и речевой их оценкой. Зачастую персонажи даже не понимают, что означают сказанные слова. Так на приёме у врача Дувра Месье воспринимает его профессиональные вопросы как вторжение в его частную жизнь.

Личная жизнь Месье может быть охарактеризована уже тем, что после разрыва с невестой он продолжает жить с ее родителями. Неувядаемость чувств здесь ни при чем, главное - это повторяемость действий, о которых не стоит задумываться. Этот мотив движения в сторону, а затем возврат в прежнее положение, напоминающий маятник, отсчитывающий время, не наполненное событиями, представлен в ряде образов романа: гамак, качалка, шезлонг, игра в пингпонг. Понять и объяснить своему ученику, что такое время и пространство остается безуспешным занятием. «Месье даже напрягшись, уже совершенно не ощущал течения времени ни на запад, ни на восток. Прежде он бы с легкостью сообразил в абстрактной, понятно, форме, что две различные субстанции, ничем не связанные между собой, одна неподвижная - это он сам, другая обтекающее его время, теперь же вызревала мысль, что нет никаких 2-х субстанций, их не существует - есть один мощный поток, беспрепятственно уносящий его за собой». ${ }^{4}$ Единственным выводом может быть мысль, что всякое движение относительно во времени.

Относительность всякого движения, двойственность и зыбкость действий, понятий в современной ускользающей и бессмысленной жизни подтверждается и отдельными чувствами, рассказами персонажа:

О проведенном опыте: «...Кошка ни жива, ни мертва - в жизни всё так»; 5

\footnotetext{
${ }^{1}$ Шервашидзе С.В. Западно-европейская литература ХХв. - М.: Флинта.2010. с.247.

2 Туссен Ж.-Ф. Месье. Режим доступа: www.royallib.ru

3 Туссен Ж.-Ф. Месье. Режим доступа: www.royallib.ru

${ }^{4}$ Туссен Ж.-Ф. Месье. Режим доступа: www.royallib.ru

5 Туссен Ж.-Ф. Месье. Режим доступа: www.royallib.ru
} 
О самочувствии: «... отсутствие боли воспринимается как удовольствие, а отсутствие удовольствия как боль, вполне, однако, терпимая». ${ }^{1}$

Повторяемость, возвращение в исходную позицию можно отметить в переезде Месье вновь в свою квартиру по соседству с Кальцем, тиранящим его печатанием своего труда по минералогии. («Месье не умел отказывать»). ${ }^{2}$ Профессор Шервашидзе В. справедливо полагает: «Повторение изначальной ситуации с Кальцем и бесполезных попыток Месье избежать, ускользнуть от тирании банальности, воплощенной в фигуре Кальца, создает образ мира, застывшего в своей агрессивной неподвижности». ${ }^{3}$ Но неподвижность по закону маятника сменяется движением. Поэтому в романе Туссена обыденная повседневная жизнь изображается как смена движения неподвижностью в постоянном повторении. Нельзя не согласиться с оценкой романов Туссена профессором Шевяковой Э.Н.: «В смеховой стихии осмысливается абсурдность существования как вечного «бега» - бесцельного застывшего бега в никуда», и тем самым он практически остраняется, насмешливо обесценивается». ${ }^{4}$

Бессодержательность бытия Месье, его ежедневного «бега по кругу» подчеркивается описанием запрограммированных повторяющихся действий персонажа с чередованием фрагментов научного текста по минералогии, физике, философии, истории.

Что же объединяет этого усредненного маловыразительного главного персонажа романа Ж.Ф. Туссена с героями философских повестей великого просветителя Вольтера. Неоднократно исследователи современной французской литературы подчеркивали её связь с литературой Просвещения. В частности профессор Шевякова Э.Н. утверждает: «Язык философской повести XVII века и ее жанровые возможности в новой художественно-эстетической системе писателей XXI века оказались необыкновенно действенными и актуальными». ${ }^{5}$

Непосредственные аллюзии просветительской литературы в произведении Туссена отсутствуют. Роман Туссена «Месье», скорее всего, предстаёт своеобразной вариацией игры с философской повестью XVIII в, где идёт скрытый диалог автора с Вольтером.

Тип героя Туссена, казалось бы, такой отличный от просветительского идеала на самом деле продолжает вольтеровскую традицию, как в осмеянии «философии оптимизма», так и «философии пессимизма», потому что в осознании относительности и нестабильности существующего мира персонажем Туссена все же есть проблеск надежды.

Как известно, жанр философской повести XVIII века отличается тем, что её герой «естественный человек» согласно критериям «разумного» взгляда на окружающий мир, так как для просветителей «разумное и естественное» были неотделимы друг от друга.

В современную эпоху это соединение утрачивает своё значение и распадается, на что небезосновательно указывает профессор Шевякова Э.Н.: «...утрачено доверие к абсолютному разуму, как критерию истины, утрачено представление об однозначности истины; понятие «естественный человек» трансформировалось. Это не дитя природы, не представитель другой ступени цивилизации - это Другой по отношению к обществу потребления». ${ }^{6}$

Персонаж Туссена - это тоже «естественный» человек, но другого времени.

Месье - одинок, он не приемлет близости с определенным количеством людей по службе и вне ее, теми, кто не понимает и не может понять его. Но из-за жажды понимания в этом чужом мире Месье неоднократно твердил своим маленьким племянницам: «Мы-то с вами друг друга понимаем». Контакты с другими людьми для Месье неприятны:

«Месье не очень-то любит особей подобных себе. Нет, не любил»;

«Телефон Месье не больно любил»;

«Месье не любил суету». ${ }^{7}$

И при том Месье, человек без имени, такой же как многие, если не все. Поэтому название романа Туссена подчеркивает обыденность, банальность, обычность описываемого.

\footnotetext{
1 Туссен Ж.-Ф. Месье. Режим доступа: www.royallib.ru

2 Туссен Ж.-Ф. Режим доступа: www.royallib.ru

${ }^{3}$ Шервашидзе В.С. Западно-европейская литература XX века. М.; Флинта, 2010, с.253

4 Шевякова Э.Н. Диссертация на соискание ученой степени доктора наук. Режим доступа: www.dissercat.com/content/sovremennaya-frantsuzskaya-proza-rubezha-vekov

5 Шевякова Э.Н. Диссертация на соискание ученой степени доктора наук. Режим доступа: www.dissercat.com/content/sovremennaya-frantsuzskaya-proza-rubezha-vekov

6 Шевякова Э.Н. Диссертация на соискание ученой степени доктора наук. Режим доступа: www.dissercat.com/content/sovremennaya-frantsuzskaya-proza-rubezha-vekov

${ }^{7}$ Ж.-Ф.Туссен. Месье. Режим доступа: www.royallib.ru
} 
После многолюдного пикника Месье должен успокоиться, прийти в себя. Он бесцельно бродит по городу, рассматривает витрины, заходит в полупустое кафе, покупает ботинки. Чтобы оторваться от людской суеты Месье придумал себе выход - прогулки на крыше, куда он для большего комфорта берёт с собой стул. Особенно его вдохновляют ночные визиты крыши. «Темнота окружала Месье со всех сторон. Он неподвижно сидел на стуле, запрокинув голову, он тонул в бездне неба, думы устремляя к изгибу горизонта. Он мысленно обнимал ночь, всю, насколько хватало памяти вселенной». ${ }^{1}$

Побег от реальности, от всего земного лучше всего удавался в мыслях о космосе. Именно о нем, звездах и созвездиях он беседует со своей новой девушкой Анной Брукхардт.

Заслуживает особого внимания частое упоминание в тексте слова «окно» - как своеобразного символа выхода, пусть и кратковременного, из окружающей действительности в иную реальность.

Особенностью персонажа Туссена является его отчуждение от современной потребительской цивилизации, в которой он вырос и стал её частью. Он пытается убежать от нее и вместе с тем научиться жить по её правилам.

Безымянный герой с его усредненностью, отсутствием индивидуального своеобразия, характерный для рубежа XX-XXI веков, интересен современным писателям как отчужденное сознание. Но и философская повесть XVIII века прибегала к этому типажу.

Туссен прибегает к такому персонажу, используя комические элементы для изображения банальной, каждодневной действительности, акцентируя и пародируя отдельные реальные явления, сцены, детали, поведение персонажей, открывает их фальшивый характер и задаётся вопросами: что такое человек? что такое жизнь? каковы их взаимоотношения? что есть истина? что есть время и вечность? Многие из этих вопросов были насущными и важными для просветителей, правда, не всегда находившим ответы на них. Задать эти вопросы гораздо важнее, чтобы побудить читателей размышлять и думать. Туссен играет с читателем, подвергая трансформации национальные литературные традиции, но оставляя главное в глобальных, проблемных вопросах. В частности, в романе «Месье» неоднократно обсуждается понятие времени», движения в пространстве, но не дается окончательного определения. Но главное, что сближает творение Вольтера, его философские повести и роман Туссена - это противостояние человеческой личности и реальной действительности.

Убеждения Кандида, героя философской повести Вольтера, воспитанные его учителем Панглосом, сторонником «философии оптимизма», утверждавшего, что «все к лучшему в этом наипрекраснейшем из миров», сильно поколебались при соприкосновении с жестокостью, ужасами современного мира, и он отказывается от теории своего учителя. Налицо конфликт между убеждениями героя и суровой действительностью.

Произведение Туссена проникнуто пониманием разрыва между реальностью и её восприятием персонажем. Вместо обстоятельного аналитического изображения действительности, в которой живет герой, и которая диктует его поведение и формирует его личность, даётся констатация отдельных фактов, действий, описание вещей, предметов, окружающих персонажа, что приобретает комическо-ироническое звучание. У Вольтера в философской повести присутствует множество сказочных чудесных элементов, которые придают описываемым событиям условный фантастический характер. В романе Туссена жизнеподобие остаётся, но лишь чисто внешнее. Современный автор насыщает описание жизненных реалий множеством самых непримечательных банальных событий, фактов, мелочных деталей, и действительность, отраженная в романе, приобретает недостоверный, гипертрофированный характер, что делает ее тоже условной. Самые обыденные, малозначительные вещи, поступки становятся в новое время нерядовыми, как нечто, заставляющее работать воображение.

\section{ЛИТЕРАТУРА}

1. Жукова П.А. Современная зарубежная проза. - М.: Наука, 2015.

2. Туссен Ж.-Ф. Месье. Режим доступа: www.royallib.ru

3. Шевякова Э.Н. Диссертация на соискание ученой степени доктора наук. Режим доступа: www.dissercat.com/content/sovremennaya-frantsuzskaya-proza-rubezha-vekov

4. Шервашидзе С.В. Западно-европейская литература XX века. М.; Флинта, 2010.

\footnotetext{
${ }^{1}$ Ж.-Ф.Туссен. Месье. Режим доступа: www.royallib.ru
} 